Akademik Drago Branković ${ }^{1}$

Akademija nauka i umjetnosti

Republike Srpske, Banja Luka
Primljen: 11.12.2019.

Prihvaćen: 16.5.2020.

ORIGINALNI NAUČNI RAD

UDK: $159.953 .5: 373.5$

$373.322: 159.953 .5$

DOI 10.19090/ps.2020.1.84-99

\title{
STAVOVI SREDNJOŠKOLACA O MODELIMA ISKUSTVENOG UČENJA
}

\author{
Apstrakt
}

Posljednje decenije u pedagoškoj nauci prepoznatljive su i po razvijanju posebne teorije iskustvenog učenja. U osnovi teorijskih shvatanja većeg broja autora nalaze se suptilni problemi iskustva, odnosa ličnog $i$ vanjskog svijeta, transformacije iskustva, iskustvenog učenja, reflesije (kritička refleksija), dometi i ograničenja (vrijednosti) iskustvenog učenja. Teorijskom analizom savremene pedagoške literature identifikovano je osam modela iskustvenog učenja: iskustveno učenje samorefleksijom, iskustveno učenje grupnom refleksijom, učenje iz doživljenog iskustva, učenje iz tuđeg iskustva, učenje iz zamišljenog iskustva, iskustveno učenje u porodici, iskustveno učenje u nastavi, iskustveno učenje u slobodnom vremenu. Cilj empirijskog istraživanja bio je ispitivanje stavova srednjoškolaca o vrijednostima osnovnih modela iskustvenog učenja. Primijenjena je empirijska naučno-istraživačka metoda (survey istraživački postupak) na prigodnom uzorku od 308 učenika srednjih škola sa područja Banja Luke, Prijedora i Mrkonjić Grada. Upotrijebljen je posebno konstruisan skaler (SVMIU) sa osam podskalera sa ukupno 40 tvrdnji na petostepenoj skali likertovog tipa. Rezultati empirijskog istraživanja potvrdili su osnovnu hipotezu da srednjoškolci imaju izgrađene statvove o vrijednosti iskustvenog učenja (Mean 3,41 od maksimalno 5,00) kao i hipotezu o međusobnoj povezanosti njihovih stavova o vrijednostima pojedinih modela iskustvenog učenja (značajnost na nivou 0,01). Rezultati istraživanja ukazuju na potrebu daljnjih proučavanja povezanosti iskustvenog učenja sa učenjem $u$ nastavi (formalno učenje) $i$ drugim oblicima neformalnog $i$ informalnog učenja.

Ključne riječi: iskustvo, transformacija iskustva, iskustveno učenje, vrijednosti iskustvenog učenja, modeli iskustvenog učenja.

1 E-mel adresa: drago.brankovic.anurs@gmail.com 


\section{Uvod}

Iskustveno učenje je pojam koji se u novije vrijeme često upotrebljava mada on u pedagoškoj nauci nije nov. Iskustvo i iskustveno učenje su nešto što je sastavni dio razvoja ljudi, škole, učenja i života. Kroz istoriju iskustveno učenje definisano je i interpertirano u skladu s vremenom u kojem se živjelo, u kontekstu stepena razvoja nauke i šireg društvenog konteksta. Svako novo saznanje produbljivalo je razumijevanje i kontekst iskustvenog učenja, a u sadašnje vrijeme „,udahnuta“ mu je nova vrijednost.

Premda se vrlo često upotrebljava pojam iskustva nije lako jasno i precizno definisati. Samorazumljivost tog pojma otvara mogućnost različitih i nepreciznih tumačenja. Tako se u filozofskoj literaturi iskustvo najčešće definiše kao „...neposredno doživljavanje, ono što je neposredno doživljeno ... skup svih na neposrednom doživljavanju zasnovanih spoznaja" (Filozofski rječnik, 1965: 190). S druge strane, sociolozi iskustvo definišu kao „...ukupnost svih doživljaja i informacija o predmetima subjektova bavljenja, odnosno o objektima njegove akcije, a koje (informacije) rezultiraju iz neposredne prakse efektornog (izvedbenog, radnog) odnošenja subjekta“ (Rječnik sociologije i socijalne psihologije, 1977: 257). U psihologiji iskustvo se pojmovno određuje kao „sveukupnost spoznaja stečenih u svakodnevnu životu u neposrednom kontaktu sa stvarnošću... Ali u tom pogledu iskustvo ima i jednu prednost; ono je rezultat vlastita doživljavanja subjekta" (Petz, 1992: 168). Sasvim opravdano u pedagogiji iskustvo se cjelovitije razumijeva i tumači kao ,proces i rezultat shvatanja objektivne stvarnosti u svijesti konkretne individue do kojeg se dolazi opažanjem, misaonom preradom i emocionalnim doživljavanjem neposrednih podataka" (Branković, 2011: 90).

Istorijski posmatrano brojni su autori pokušavali dati cjelovitije definicije iskustvenog učenja. HEQCO (HEQCO Higher Education Quality Council Of Ontario, 2016) u svom praktičnom vodiču navodi definiciju Robertsa (Roberts, 2012) prema kojoj se iskustveno učenje odnosi na posebne tehnike ili mehanizme koje pojedinac može primijeniti za sticanje znanja ili ostvarivanje ciljeva učenja. S druge strane Keton i Tate (Keeton i Tate, 1978) smatraju da je učenje iskustveno kada uključuje neposredan susret sa fenomenom koji se proučava a ne samo razmišlja o njemu. Beard i Vilson (Beard \& Wilson, 2013) prepoznaju iskustvo kao „most“ između pojedinca i njegovog vanjskog okruženja, dok Boud (Boud, 1999) ukazuje na malu vrijednost odvajanja učenja od iskustva s obzirom da je iskustvo glavni moderator učenja. Prema definiciji Davida Kolba (Kolb, 1984) iskustveno učenje je proces u kojem se znanje stvara kroz preoblikovanje iskustva, a Beard i Wilson (2013) naglašavaju da se unatoč velikom značaju iskustva u učenju mora naglasiti da učenje nije automatski rezultat iskustva. Iskustveno učenje prema shvatanjima N. Pastuović (Pastuović, 2008) zbiva se u različitim životnim ulogama i okruženjima, a D. Branković piše da je ,iskustveno učenje kontinuiran proces kritičke evaluacije vlastitog ili tuđeg iskustva koje kroz cikličnu transformaciju (konkretno iskustvo, refleksivna opservacija, konceptualizacija, aktivno eksperimentisanje) ranijeg iskustva i interakciju osobe i okoline vodi sticanju novih znanja“" (Branković, 2011: 95). Iskustveno učenje je zapravo mentalna obrada nekog iskustva bilo ono vanjsko ili unutrašnje a koje obogaćuje znanja ili razvija sposobnosti. 
Novije teorije iskustvenog učenja u definiciju uključuju i shvatanja o višestrukoj inteligenciji H. Gardnera i koncepciju emocionalne inteligencije D. Golemana. Gardner (Gardner, 1993) smatra da posjedujemo vrlo složen skup sposobnosti kojima se koristimo u rješavanju problema a Goleman (Goleman, 1995) piše da emocionalna inteligencija razvija svijest o emocijama i pomaže da se one razumiju i prihvate. Propitujući naše vezanosti za određena emocionalna iskustva možemo prevladati iskustvo i vidjeti ga drugačije. Emocionalno stanje utiče na učenikov kapacitet za učenje jer „,središnje načelo u iskustvenom učenju je da učenje uključuje cijelu osobu, uključujući emocionalne, socijalne, fizičke, kognitivne i duhovne aspekte osobnosti” (Kohonen, Riitaa, Pauli, Jorma, 2001: 27). Stoga je iskustveno učenje retrospektivno, kritičko, analitičko, racionalno i lično (Malinen, 2000). Svako učenje ili obrazovanje koje se naziva iskustvenim ima iskustvo kao središnju tačku svakog pa i iskustvenog učenja.

\section{Teorijski pristup istraživačkom problemu}

Socijalna pedagogija K. Lewina, progresivna pedagogija J. Deweya i razvojni konstruktivizam Jeana Piageta bili su podloga na kojoj je D. Kolb razvio teoriju iskustvenog učenja zasnovanu na transformaciji iskustva. Kolbov ciklički model (Kolb, 1984) koji čini suštinu teorije iskustvenog učenja utemeljen je na šest odrednica (pretpostavki): a) učenje je proces kontinuirane transformacije iskustva, b) svako učenje uključuje i preispitivanje već naučenog, v) učenje je stalno osciliranje između polova dimenzija: doživljaja i razmišljanja, refleksije i akcije, g) učenje je holistički adaptivni proces koji uključuje cijelu osobu, d) učenje je transakcijski proces između osobe i okoline, i đ) ishod učenja su konstrukcije ličnog saznanja o svijetu. Dinamika učenja kojom se iskazuje suština tog procesa ostvaruje se povezivanjem vlastite prakse sa teorijom. U međusobnim odnosima ,vlastitog iskustva i teorije za ličnost koja uči relevantna je svjesnost cilja i sadržaja učenja, osposobljenost za samoodlučivanje, te samoodgovornost za sticanje novog znanja" (Branković, 2011: 94). Kolbova teorija iskustvenog učenja počiva na učenju kao procesu čiju suštinu čini transformacija iskustva shvaćenog kao kombinacija sticanja i preoblikovanja iskustva (Kolb, 2015). Takva transformacija iskustva obuhvata dva postupka: prvi, sticanja iskustva: konkretno iskustvo (CE) i apstraktno posmatranje (AC) i drugi, transformacija iskustva: refleksivno posmatranje (RO) i aktivno eksperimentiranje (AE). U okviru cikličnog modela, prema shvatanjinma Kolba, nalaze se četiri funkcionalno integrisane faze: konkretno iskustvo, refleksivno posmatranje, apstraktno promišljanje i aktivno eksperimentiranje.

U razvijanju teorije iskustvenog učenja Dž. Kovan (Cowan, 2006) dao je nove elemente povezujući Kolbov i Schönov model iskustvenog učenja. Iz Kolbovog modela preuzeo je shvatanje relacija (generalizacija, planiranja testiranja generalizacija, iskustvo i analitičke refleksije) a iz Schönov modela refleksiju (refleksije u akciji i refleksije o akciji). Model refleksivnog učenja s višestrukim petljama bio je osnova za dogradnju i razvijanje novih teorija iskustvenog učenja većeg broja naučnika. Tako je model sa dvije petlje proširen na model sa tri (refleksiju u akciji, refleksiju o akciji 
i refleksiju o refleksiji) a Covan i Stroud (Cowan \& Stroud, 2016) dodali su i četvrti nivo refleksije (prethodna refleksija ili refleksija prije akcije).

Teorija iskustvenog učenja obogaćena je i novim shvatanjima odnosa ličnog i vanjskog svijeta. Tako Beard i Vilson (Beard \& Wilson, 2013) iskustveno učenje su i definisali kao specifičan proces u kojem dolazi do „razumijevanja smisla kroz interakciju unutarnjeg osobnog s vanjskim svijetom" (Cowan, Stroud, 2016: 19). I tako stečeno iskustvo, automatski ne dovodi do iskustvenog učenja, već samo ono iskustvo koje stvara situaciju u kojoj ličnost analizira doživljeno, shvata uzroke i posljedice (reflektira) određenog iskustva. Posmatrano sa tog aspekta svako iskustvo je lično pa i njegovo doživljavanje i reflektovanje su takođe lični (Van Manen, Max, 1977). John Mezirow (prema Kitchenham, 2008) taj proces razrađuje tako da se interpretacijom iskustva stvara smisao (značenje) a interpretacijom smisla dolazi do procesa učenja. Kritička refleksija, prema njegovom shvatanju, čini osnovu transformacijskog učenja kao jednog od najsloženijih oblika učenja. Smisao iskustva nije u vanjskim oblicima života već u unutrašnjoj strukturi ličnosti do kojih se dolazi kroz ljudske interakcije i komunikacije (Kitchenham, 2008).

U tumačenju učenja iz iskustva neophodno je poznavanje osnovnih pretpostavki (karakteristika) tog specifičnog procesa. David Boud (Boud, 1999) piše o takvih pet pretpostavki: a) iskustvo je temelj i posticaj za učenje, b) učenici aktivno konstruišu vlastito iskustvo, v) učenje je holistički proces g) učenje je društveno i kulturno konstruisano, i d) učenje je pod utjecajem socio-emocionalnog konteksta u kojem se pojavljuje. Učenje je aktivno korištenje cjelokupnog relevantnog iskustva a posebno onog iz ranijeg iskustvenog učenja kao i kritičko reflektiranje (Branković, Perović, 2018) ranijeg iskustva koje uključuje ne samo intelekt i emocije, već i facilitaciju i procjenu ishoda učenja. Stoga je opravdano shvatanje Petera Jarvisa prema kojem je iskustveno učenje „svuda oko nas, ono oblikuje i pomaže kreirati naše živote - tko smo, što činimo. Ono uključuje bavljenje složenim i nesavladivim problemima, ono zahtijeva ličnu predanost, koristi interakciju s drugima i zaokuplja naše emocije i senzibilitet, što je neodvojivo od utjecaja konteksta i kulture" (Jarvis, 2003: 141). Iskustveno znanje (znanje stečeno kroz iskustveno učenje) obuhvata senzibilitet, emocije, intuiciju, maštu, razmišljanje, razlučivanje, namjeru i djelovanje. I ne samo to, iskustveno znanje pokazuje koliko se osoba odmakla od ličnog iskustva na druge nivoe: imaginacijsku, koncepcijsku i praktičnu. Na tom shvatanju John Heron je konstruisao model isustvenog učenja koji sadrži četiri dimenzije: iskustvenu, imaginacijsku, pojmovnu (koncepcijsku) i praktičnu (Heron, 1999).

Kao metodološki nov i nedovoljno sagledan problem predstavljaju vrijednosti iskustvenog učenja u uslovima razvoja cjeloživotnog učenja. Problem odnosa cjeloživotnog učenja (cjeloživotno obrazovanje) $i$ iskustvenog učlenja našao se u fokusu interesovanja većeg broja naučnika. I UNESCO je posebnim dokumentom (United Nations Decade of Education for Sustainable Development, 2005), u središte stavio plansko osvješćavanje i usmjeravanje ljudi prema shvatanju važnosti održivog razvoja za život čovjeka. Tom opredjeljenju data je prednost u svim strategijama aktivnog i iskustvenog, inovativnog i budućnosti usmjerenog učenja (Uzelac, Vujičić, 2008). 
Za predstojeće progresivne promjene neophodno je formirati i nove kompetencije nastavnika za učenje putem iskustva (iskustveno učenje). Kompetencije kao skup znanja i vještina, vrijednosti, osobina ličnosti, stavova i motivacije pojedinca nije moguće sticati bez iskustvenog učenja. Jer nisu knjige pa niti učiteljeve riječi jedini izvori znanja za učenike. „Nisu to čak niti najsuvremeniji računarski programi uz najsuvremeniju tehniku za vizualnu prezentaciju. U prvi plan izlaze neposredna iskustva učenika, napose iskustva u izvornoj stvarnosti (što podrazumijeva i razne vidove socijalnog učenja), te iskustva s konkretnim materijalima" (Matijević, 2006: 21). Formiranje i razvijanje kompetencija uključuje i različite modele iskustvenog učenja, mijenjanje uloge nastavnika i primjenu specifičnih metoda i tehnika učenja. Knovles, Holton i Svanson naglašavaju da učenicima treba približiti nove mogućnosti, pomoći u dijagnosticiranju i analizi jaza između dosadašnjih obrazovnih postignuća i budućih obrazovnih potreba, davati im stručnu podršku u procesu učenja i samoevaluaciji, kao i pružati smjernice i pomoć u iskorištavanju vlastitih iskustva kao resursa za učenje kroz korištenje raznih tehnika (Knowles, 1990). Iskustveno učenje omogućava visoko učinkovit ,alat“ za sticanje dinamičkog znanja. S druge strane, Canon i Feinstein (Cannon i Feinstein, 2005) povezuju Bloomovu taksonmiju i iskustveno učenje koristeći novi okvir za razvoj obrazovnih ciljeva iskustvenog učenja.

U novom području STEM (science, technology, engineering i mathematics) Malinda Vilson Gilmore (Gilmore, 2013) smatra da je ključ poboljšanja u upravo u iskustvenom učenju i da je neophodno koristiti sve mogućnosti koje ono pruža, što zapravo iskustvenom učenju daje izuzetno važnu ulogu u edukaciji budućnosti. Odnose iskustvenog učenja sa integrisanim cjeloživotnim obrazovanjem u vidu posebnog modela prestavio je Richards $(2011 ; 2016)$ kojim prikazuje relevantne komponente okvira integrisanog cjeloživotnog obrazovanja (Šema1).

Šema 1.

Okvir integriranog cjeloživotnog obrazovanja (optimalno cjeloživotno učenje)

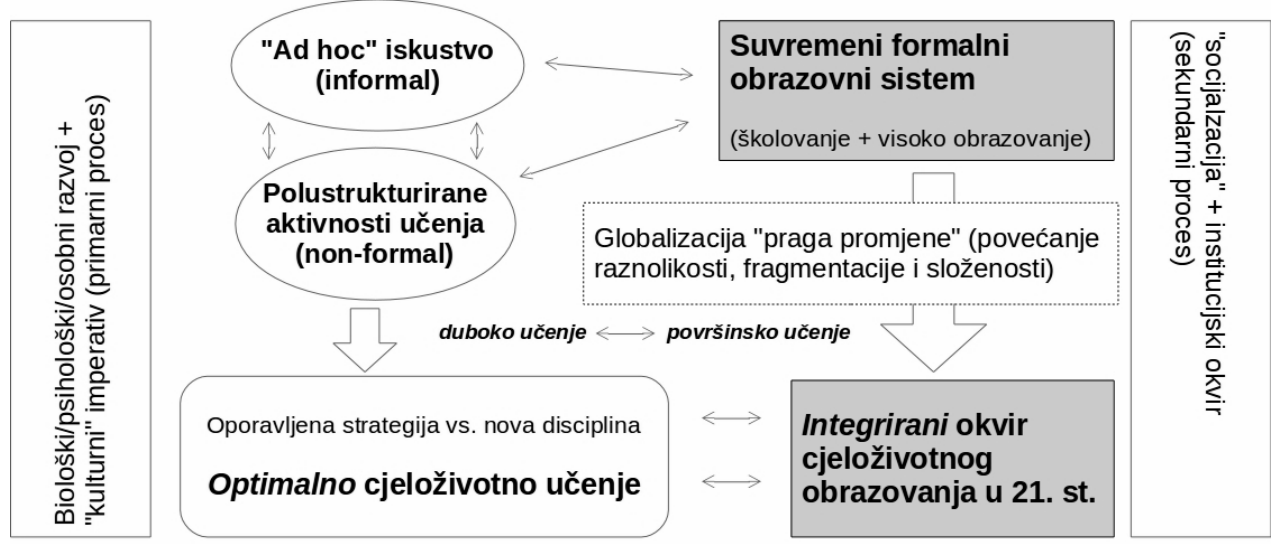


Izvor: Prilagođeno prema Richards, C. K. \& Charungkaittkul, S. (2016). The eight pillars of lifelong education: Thailand studies

Predstavljeni okvir ukazuje na dva osnovna kontrasta, prvi između današnje moderne formalne škole i budućeg integrisanog okvira cjeloživotnog obrazovanja, te drugi kontrast, između tog integriranog okvira za cjeloživotno obrazovanje i nove paradigme u nastajanju „optimalnog cjeloživotnog učenja“ kao primarnog procesa iskustva i razvoja. Duboko učenje (refleksija) je izuzetak i samo je dodatak tendenciji „površinskog“ učenja u savremenom formalnom obrazovanju. Stoga C.K. Ričards posebno ističe da su vrlo važne uloge budućeg okvira cjeloživotnog obrazovanja za podršku i podsticanje optimalnog učenja, konstruktivne izgradnje znanja i refleksivne prakse u cijelom nizu formalnih, kao i informalnih i non-formalnih konteksta učenja. Cjeloživotno učenje nastavnika za ostvarivanje njegovih suptilnih kompetencija u procesima sticanja znanja učenika uključuje i superviziju koja bi im pomagala da reflektiraju svoje postupke u oblasti novih oblika učenja (Branković, Cajvert, Puhalić, 2019).

Predstavljena teorijska shvatanja pokazuju da autori na različite načine definišu pojam iskustva $i$ iskustvenog učenja. Velik je broj onih koji su u različitim razvojnim fazama dali značajan doprinos uobličavanju teorije iskustvenog učenja (Branković, Perović, 2017a). Na globalnom nivou društvo koje uči, cjeloživotno obrazovanje i cjeloživotno učenje vrlo su usko povezani sa modelima učenja (Vizek-Vidović. 2007), iskustvom $\mathrm{i}$ iskustvenim učenjem.

Kritičkom analizom relevantne literature identifikovali smo veći broj modela iskustvenog učenja. U nedostatku preciznijih kriterija njihovo identifikovanje i grupisanje izvršeno je primjenom tzv. ukrštenog kriterijuma. Primjenom takvog kriterijuma identifikovali smo osam osnovnih modela iskustvenog učenja:

- Model iskustvenog učenja samorefleksijom,

- Model iskustvenog učenja grupnom (timskom) refleksijom,

- Model učenja iz doživljenog iskustva,

- Model učenja iz tuđeg iskustva,

- Model učenja iz zamišljenog iskustva,

- Model iskustvenog učenja u porodici,

- Model iskustvenog učenja u nastavi,

- Model iskustvenog učenja u slobodnbom vremenu.

Nesporna je činjenica da će različitost teorijskih shvatanja i interpretacija podstaknuti nova teorijska promišljanja i empirijska istraživanja iskustvenog učenja. Kao metodološki nov i nedovoljno sagledan problem predstavljaju vrijednosti iskustvenog učenja u uslovima dominantnih uticaja savremenih informatičkih tehnologija na učenje. 


\section{Metod istraživanja}

Istraživački nacrt o vrijednosti osnovnih modela iskustvenog učenja učenika srednjih škola primjeren je složenosti problema iskustvenog učenja ali i specifičnostima kvantitativnih istraživanja (Branković, Perović, 2017 b) pedagoških fenomena.

$\mathrm{Na}$ osnovu kritičke analize teorijskih osnova i iskustvenog učenja definisan je istraživački problem ${ }^{2}$ (stavovi o vrijednostima iskustvenog učenja) i utvrđen cilj kao empirijsko istraživanje vrijednosti osnovnih modela iskustvenog učenja učenika srednjih škola sa dva istraživačka pitanja: 1 . Da li srednjoškolci imaju formirane (i na kojem su nivou) stavove o vrijednostima modela iskustvenog učenja? 2) Da li postoji međusobna povezanost između stavova srednjoškolaca o vrijednostima pojedinih modela iskustvenog učenja? Istraživanje je koncepcijski postavljeno tako da se u njemu vrši provjera (testiranje) dvije istraživačke hipoteze: prva, nivo izgrađenosti stavova učenika srednjih škola o vrijednostima osnovnih modela iskustvenog učenja i druga, postojanje međusobne povezanost između stavova o različitim modelima iskustvenog učenja (samorefleksija; grupna refleksija; učenje iz doživljenog iskustva; učenje iz tuđeg iskustva; učenje iz zamišljenog iskustva; iskustveno učenje u porodici; iskustveno učenje u nastavi; iskustveno učenje u slobodnom vremenu). Primjenjena je deskriptivna naučno-istraživačka metoda (survey istraživački postupak) sa tehnikom skaliranja. Za potrebe ovog istraživanja konstruisan je poseban skaler (SVMIU) sa osam podskalera. Ukupan broj od 40 tvrdnji podijeljenih u osam grupa (podksalera). Za svaku od 40 tvrdnji konstruisana je petostepena skala likertovog tipa. Prigodan uzorak (grupni uzorak - odjeljenja) za ovo istraživanje činili su učenici srednjih škola (Banja Luka, Prijedor i Mrkonjić Grad) sva četiri razreda sa ukupno 308 učenika sa sljedećom strukturom: učenici prvog 33 (10.7\%), drugog 47 (15.3\%), trećeg 127 (41,2\%) i četvrtog razreda $101(32.8 \%)$. Podaci dobijeni primjenom skalera o vrijednostima osnovnih modela iskustvenog učenja srednjoškolaca obrađeni su izračunavanjem statističkih modela deskriptivne statistike (SPSS 17.0 FOR Windows statistički paket).

\section{Rezultati empirijskog istraživanja}

Skalerom čija je validnost i pouzdanost utvrđena u preliminarnom istraživanju ispitani su stavovi učenika srednjih škola o vrijednostima osnovnih modela iskustvenog učenja. Instrumentom su prikupljeni i grupisani podaci o samorefleksiji, grupnoj refleksiji, učenju iz doživljenog vlastitog iskustva, učenju iz tuđeg iskustva, učenja iz zamišljenog iskustva, iskustvenom učenju u porodici, iskustvenom učenju u nastavi i iskustvenom učenju u slobodnom vremenu. Rezultati dobiveni procjenama odnose se samo na ispitanike u uzorku za čiju obradu je primijenjena deskriptivna analiza.

2 Istraživanje čije rezultate prikazujemo dio je šireg istraživačkog projekta „Vrijednosti iskustvenog učenja učenika srednjih škola“ u okviru kojeg su proučavane teorije iskustvenog učenja, te ispitivani stavovi srednjoškolaca o većem broju problema iskustvenog učenja. 


\section{Stavovi srednjoškolaca o vrijednostima modela iskustvenog učenja}

U okviru prve istraživačke hipoteze je provjeravana valjanost pretpostavke o stavovima srednjoškolaca o vrijednostima iskustvenog učenja u cjelini i prema pojedinim modelima iskustvenog učenja. U Tabeli 1 predstavljeni su rezultati statističke obrade stavova učenika prema modelima iskustvenog učenja.

Tabela 1.

Stavovi učenika o vrijednostima modela iskustvenog učenja

\begin{tabular}{lccccccc}
\hline Varijable & $\mathrm{N}$ & Min. & Max. & Mean & Std.Dev. & Sk & $\mathrm{Ku}$ \\
\hline Samorefleksija & 302 & 1.00 & 5.00 & 3.3649 & .69432 & -.570 & 1.142 \\
Grupna refleksija & 302 & 1.00 & 5.00 & 3.2232 & .82976 & -.481 & .082 \\
Učenje iz doživljenog is. & 291 & 1.00 & 5.00 & 3.7588 & .71164 & -.889 & 1.430 \\
Učenje iz tuđeg iskustva & 300 & 1.00 & 5.00 & 3.2908 & .74916 & -.454 & -.133 \\
Učenje iz zam.iskustva & 302 & 1.00 & 5.00 & 3.8020 & .77751 & -.622 & .440 \\
IU u porodici & 298 & 1.00 & 5.00 & 3.6040 & .84645 & -.531 & .197 \\
IU u nastavi & 301 & 1.00 & 5.00 & 2.8944 & .81984 & .081 & .692 \\
IU u slobodnom vremenu & 302 & 1.00 & 5.00 & 3.4172 & .75503 & -.504 & .692 \\
\hline TOTAL & 299 & 1.00 & 5.00 & 3.4122 & .7662 & -.513 & -.598
\end{tabular}

U prethodnoj tabeli (Tabela 1) predstavljeni su osnovni statistički pokazatelji koji pokazuju visoke vrijednosti aritmetičkih sredina (od 2.89 do 3,80) i standardnih devijacija (od .69 do .85) za svaki model iskustvenog učenja. Pored tih izračunate su i vrijednosti aritmetičke sredine za sve modele (Total) koja iznosi 3,41 (maksimalna 5.00) uz standardnu devijaciju od .7662. Takve vrijednosti aritmetičke sredine od 3,41 u odnosu na maksimalnu 5,00 omogućava izvođenje zaključka da srednjoškolci imaju formirane pozitivne stavove o vrijednostima iskustvenog učenja. Aritmetičke sredine po podskalerima (modelima) pokazuje da srednjoškolci različito procjenjuju vrijednosti pojedinih modela iskustvenog učenja. Najvišu vrijednost, prema njihovim procjenama, ima učenje iz zamišljenog iskustva $(\mathrm{M}=3.80)$, a samo nešto manju $(\mathrm{M}=3,76)$ ima učenje iz doživljenog iskustva. Najnižu skalnu vrijednost $(M=2.89)$ i negativnu usmjerenost ima iskustveno učenje u nastavi.

Statističkom obradom podataka obuhvaćena je i njihova distribucija u odnosu na normalnu raspodjelu. Izračunati skjunis (Sk) predstavlja iskrivljenost i pokazatelj je horizontalnog odstupanja (nagib distribucije na varijabli koji pokazuje asimetričnost ulijevo ili udesno) što kod ovog istraživanja pokazuje da nijedna distribucija značajno ne odstupa od normalne raspodjele. Isto tako izračunate vrijednosti skjunisa pokazuju da sve varijable (modeli iskustvenog učenja) izuzev iskustvenog učenja u nastavi (.081) imaju pozitivnu asimetriju najviše izraženu kod učenja iz doživljenog iskustva (-.889), zatim kod učenja iz zamišljenog iskustva (-.622) i samorefleksije (-570). Pozitivnu orijentaciju 
nadalje imaju i iskustveno učenje u porodici (-.531), iskustveno učenje u slobodnom vremenu (-.504), grupna refleksija (-.481) i učenje iz tuđeg iskustva (-.454). Kurtozis $\mathrm{Ku})$ koji pokazuje spljoštenost distribucije (pokazatelj vertikalnog odstupanja - grupisanost oko aritmetičke sredine) kod ovog istraživanja statistički značajne vrijednosti (veće od +/-1) izračunate su za dva slučaja: učenja iz doživljenog iskustva $(\mathrm{Ku}=1.340)$ i učenja samorefleksijom $(\mathrm{Ku}=1.142)$. Statistički nemaju značajne vrijednosti kurtozisa za iskustveno učenje u slobodnom vremenu $(\mathrm{Ku}=.692)$, učenja iz zamišljenog iskustva $(\mathrm{Ku}=.440)$, iskustvenog učenja u porodici $(\mathrm{Ku}=.197)$, grupne refleksije $(\mathrm{Ku}=.082) \mathrm{i}$ iskustvenog učenja u nastavi $(\mathrm{Ku}=.012)$ kao i u slučaju učenja iz tuđeg iskustva $(\mathrm{Ku}=-.133)$. Iz tih pokazatelja možemo zaključiti da učenici imaju daleko najpozitivnije stavove prema učenju iz doživljenog vlastitog iskustva i samorefleksije, odnosno da su to područja koja za njih imaju najveće vrijednosti. Ostale vrijednosti modela značajno ne odstupaju uključujući i učenje iz tuđeg iskustva koje jedino od ispitanih ima negativnu vrijednost, premda ne jako izraženu (nije statistički značajna).

Dodajući navedenim pokazateljima i činjenicu da su sve vrijednosti aritmetičkih sredina nešto iznad sredine raspona minimuma (Min) i maksimuma (Max) možemo zaključiti da učenici imaju formirane pozitivne stavove o iskustvenom učenju. Srednjoškolci su iskazali najniži nivo vrijednosti za iskustveno učenje u nastavi pa se iz toga može zaključiti da iskustveno učenju u nastavi nije implementirano niti se ono praktično primjenjuje na adekvatan način i(li) da se iskustvo u nastavi ne koristi prema zahtjevima savremene pedagogije.

Predstavljeni statistički pokazatelji omogućavaju prihvatanje (potvrdu) prve hipoteze da učenici srednjih škola imaju izgrađene pozitivne stavove o vrijednostima iskustvenog učenja, te da različito procjenjuju vrijednosti pojedinih modela iskustvenog učenja.

\section{Međusobna povezanost stavova o modelima iskustvenog učenja}

Pretpostavka (druga hipoteza) o postojanju korelacija između svih modela iskustvenog učenja testirana je izračunavanjem koeficijenata korelacije i njihove statističke značajnosti na dva nivoa: .01 i .05. Statistički značajne razlike na nivou $.01(99 \%$ sigurnosti-pouzdanosti) i na nivou 0.05 (95\% sigurnosti-pouzdanosti) prikazani su u Tabeli 2. Sve korelacije statistički su značajne na nivou 0.01 (**) što nije čest slučaj u sličnim istraživanjima. 
Tabela 2.

Korelacije stavova između osnovnih modela iskustvenog učenja

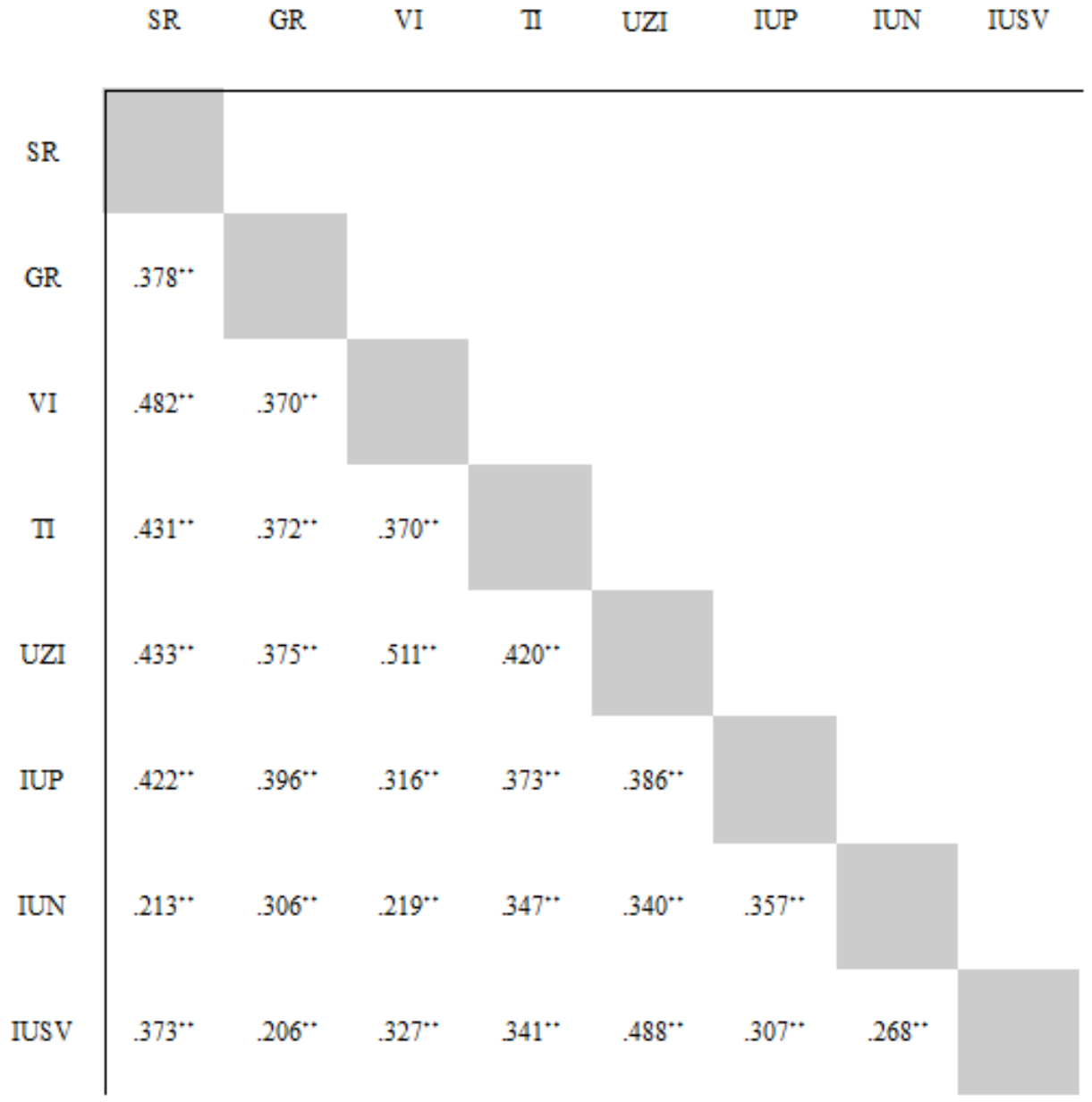

Legenda varijabli:

SR-samorefleksija,GR-grupna refleksija, VI-učenje iz doživljenog (vlastitog) iskustva, TI - učenje iz tuđeg iskustva, ZI - učenje iz zamišljenog iskustva, IUP - iskustveno učenje u porodici, IUN - iskustveno učenje u nastavi, IUSV - iskustveno učenje u slobodnom vremenu.

Rezultati prikazani u Tabeli 2 pokazuju da postoje statistički značajne korelacije (značajnost 0.01) između svih modela iskustvenog učenja. I pored tog osnovnog saznanja preciznija unutrašnja analiza pokazuje da je moguće, ali i metodološki op- 
ravdano, koeficijente korelacije razvrstati u tri grupe: a) visoki koeficijenti korelacije $(.400-.520)$, b) prosječni koeficijenti korelacije ( .300 - .399) i v) niski koeficijenti korelacije $(.200-.299)$.

Visoka povezanost (koeficjenti .520 - .300) dobivena je između sedam modela iskustvenog učenja (Tabela 3).

Tabela 3.

Najviši statistički značajni koeficjenti povezanosti

Prva varijabla Druga varijabla

Učenje iz doživljenog iskustva Učenja iz zamišljenog iskustva Nivo povezanosti

Učenja iz zamišljenog iskustva

Učenja u slobodnom vremenu

.511

Učenje samorefleksijom

Učenje iz doživljenog iskustva

.488

Učenje samorefleksijom

Učenja iz zamišljenog iskustva

.482

Učenje samorefleksijom

Učenja iz tuđeg iskustva

.433

Učenje samorefleksijom

Iskustveno učenje u porodici

Učenja iz zamišljenog iskustva Učenje iz tuđeg iskustva

Analiza navedenih koeficjenata korelacije ukazuje da najveća povezanost postoji između učenja iz doživljenog iskustva i učenja iz zamišljenog iskustva kao i između učenja iz zamišljenog iskustva i iskustvenog učenja u slobodnom vremenu. I ovi pokazatelji kao i kod sličnih istraživanja potvrđuju fundamentalno saznanje da je iskustveno učenje u osnovi lično (personalno) učenje.

Prosječna povezanost (.300 - .399) izračunata je za 17 koeficijenta (Tabela 5).

Tabela 4.

Prosječni statistički značajni koeficjenti povezanosti

Prva varijabla

Učenje grupnom refleksijom

Učenja iz zamišljenog iskustva

Učenje samorefleksijom

Učenje grupnom refleksijom

Učenje samorefleksijom

Učenje iz tuđeg iskustva

Učenje grupnom refleksijom

Učenje iz doživljenog iskustva

Učenje grupnom refleksijom

Iskustveno učenje u porodici

Iskustveno učenje u nastavi

Učenje iz tuđeg iskustva

Učene iz zamišljenog iskustva

Učenje u slobodnom vremenu
Druga varijabla

Iskustveno učenje u porodici

Iskustveno učenje u porodici

Učenje grupnom refleksijom

Učenja iz zamišljenog iskustva

Učenja u slobodnom vremenu

Učenje u porodici

Učenje iz tuđeg iskustva

Učenje iz tuđeg iskustva

Učenje iz doživljenog iskustva

Iskustveno učenje u nastavi

Učenje iz tuđeg iskustva

Učenje u slobodnom vremenu

Iskustveno učenje u nastavi

Učenje iz doživljenog iskustva
Nivo povezanosti

.396

.386

.378

.375

.373

.373

.372

.370

.370

.357

.347

.341

.340

.327 
Iskustveno učenje u porodici Učenje iz vlastitog iskustva $\quad .316$

$\begin{array}{lll}\text { Iskustveno učenja u porodici Učenje u slobodnom vremenu } & .307\end{array}$

Iskustveno učenje u nastavi Učenja iz grupne refleksije 306

U treću grupu najnižih povezanosti svrstani su odnosi između četiri koeficijenta (Tabela 5).

Tabela 5 .

Najniži statistički značajni koeficijenti povezanosti

Prva varijabla Druga varijabla

Nivo povezanosti

Iskustveno učenje u nastavi Učenje u slobodnom vremenu 268

Učenje iz doživljenog iskustva Iskustveno učenje u nastavi $\quad .219$

$\begin{array}{ll}\text { Učenje samorefleksijom } \quad \text { Iskustveno učenje u nastavi } & .213\end{array}$

Učenje grupnom refleksijom Učenje u slobodnom vremenu 206

Posmatrano u cjelini (zajednički nivo) rezultati istraživanja pokazuju da postoje značajne korelacije između stavova o svim modelima iskustvenog učenja, a logička analiza ukazuje na nivo povezanost između stavova o pojedinim modelima iskustvenog učenja. Tako najznačajnija i najizraženija korelacija između učenja iz doživljenog iskustva i učenja iz zamišljenog iskustva, nešto malo manja između učenja iz zamišljenog iskustva $i$ iskustvenog učenja u slobodnom vremenu, te samorefleksije i učenja iz vlastitog iskustva. Iz toga se može zaključiti da učenici srednjih škola različito procjenjuju vrijednosti pojedinih modela iskustvenog učenja. Nastavnike i pedagoge upozorava podatak da su najniži koeficijenti povezanosti izračunati za odnose iskustvenog učenja u nastavi sa svim drugim modelima iskustvenog učenja što upućuje na zaključak da učenici iskustveno učenje u nastavi ne prepoznaju i da ga nastavnici ne koriste u procesima sticanja znanja.

Uzimajući u obzir činjenicu da su sve korelacije značajne i na nivou 0.01 , može se zaključiti da postoji povezanost između stavova srednjoškolaca o svim modelima iskustvenog učenja čime je dokazana i druga hipoteza ovog istraživanja.

\section{Diskusija i Zaključak}

Kritičko proučavanje shvatanja većeg broja savremenih filozofa, psihologa, pedagoga $\mathrm{i}$ andragoga pokazuje da se u uslovima dominantnog uticaja informacionih tehnologija na cjelokupni život sve više pažnje posvećuje iskustvenom učenju. Različite teorije i rezultati empirijskih istraživanja ukazuju na vrijednosti iskustvenog učenja u razvoju ličnosti i ljudskog društva. Rezultati multidisciplinarnih istraživanja dokazali su postojanost i integrisanost unutrašnjeg i vanjskog svijeta koja se ispoljava kroz saznajne procese u okviru kojih iskustveno učenje ima poseban značaj. U našem, kao i većem broju tangentnih empirijskih istraživanja, dokazuje se povezanost isku- 
stvenog učenja sa školskim i životnim situacijama kao i drugim oblicima formalnog i neformalnog učenja.

Učenici srednjih škola čiji su stavovi istraživani pokazali su da oni imaju formirane stavove o visokim vrijednostima iskustvenog učenja (mean 3,41). Iskustveno učenje, a posebno model učenje iz vlastitog iskustva, ima više prednosti u odnosu na druge vidove učenja. Do takvih saznanja došao je i S. Gold (Gold, 2001) identifikujući prednosti iskustvenog učenja koje se odnose na fleksibilnost, uklanjanje barijera, izbor vremena učenja kao i razlike u stilovima učenja. U našem istraživanju potvrdili smo hipotezu da su stavovi o vrijednostima osnovnih modela iskustvenog učenja različiti (mean od 2.89 do 3,80 ) na što su ukazali i rezultati i drugih istraživača (Jordi, 2011). Srednjoškolci su najniže vrijednosti procijenili kod modela iskustvenog učenja u nastavi (mean 2,89) što ukazuje na nizak nivo kompetencija nastavnika za primjenu iskustvenog učenja u nastavnom procesu. $\mathrm{Na}$ istraživanju studentske populacije J.D. Hover (Hoover, 2011) došao je do zaključka da studenti posjeduju samo-kontradiktoran set osobina bitnih za iskustveno učenje koji od nastavnika zahtijevaju isotvremenu primjenu specifičnih tehnika i metoda učenja. Iskustveno učenje na osnovu zamišljenog iskustva, prema procjeni srednjoškolaca u našem istraživanju, ima najviše skalne vrijednosti. U tom modelu učenja postoji najviše mogućnosti samoregulacijskog pristupa kojima se, i prema istraživanjima R. L. Gifitha i saradnika (Griffith, Steelman, Wildman, LeNoble \& Zhou, 2017), promoviše percepcija sebe, društvenog okruženja, podstiče kritičko mišljenje i izoštrava vlastiti fokus.

Rezultati našeg istraživanja potvrdili su hipotezu da postoji povezanost između procjena vrijednosti svih modela iskustvenog učenja. U istraživanju je kroz procjenu vrijednosti dva modela (samorefleksija; grupna refleksija) istraživan i problem refleksije u iskustvenom učenju. Prosječne skalne vrijednosti za oba modela su visoke (samorefleksija 3,36; grupna refleksija 3,22). I rezultati drugih istraživanja ukazali su na važnost refleksije pa je neophodan sistematski i razvojni pristupi obučavanja nastavnika za refleksivno učenje (Ryan \& Ryan, 2013). Prema rezultatima istraživanja R.Jordi refleksivna praksa posebno ona u nastavnom procesu integriše različite dimenzije čovjekove svijesti (Jordi, 2011). Na takvo saznanje ukazuju i rezultati našeg istraživanja prema kojima srednjoškolci nisko vrednuju postojeće iskustveno učenje u nastavi (mean 2,89).

Rezultati našeg istraživanja saglasni su sa većim brojem rezultata tangentnih istraživanja i omogućavaju izvođenje osnovnog zaključka da je u nastavi kao najorganizovanijem obliku učenja kao i u drugim oblicima (neformalno i informalno obrazovanje) moguće koristiti strukturirana iskustva koja će kod onih koji uče (učenici, studenti, polaznici) podsticati znatiželju, motivaciju i pokretati ih na preuzimanje odgovornosti za procese vlastitog učenja i njegove ishode. Takve promjene treba posmatrati kao kontinuirani proces kojeg je neophodno sistematski istraživati ne samo u kvantitativnim, već i kvalitativnim i evaluacijskim istraživanjima. Iskustveno učenje a posebno njegovi modeli u budućnosti postaće novi izazov za veći broj istraživača. 


\title{
Drago Branković
}

\section{SECONDARY SCHOOL STUDENTS' ATTITUDES TOWARDS EXPERIENTIAL LEARNING MODELS}

\begin{abstract}
The last decades in pedagogical science are also recognizable by the development of a special theory of experiential learning. The theoretical understandings of many authors are based on subtle problems of experience, personal and external world relations, transformation of experience, experiential learning, reflection (critical reflection), scope and limitations (values) of experiential learning. In the theoretical analysis of contemporary pedagogical literature eight models of experiential learning have been identified: experiential learning by self-reflection, experiential learning by group reflection, learning from personal experience, learning from others' experience, learning from imagined experience, experiential learning in the family, experiential learning during instruction, experiential learning in free time. The aim of this empirical research was to examine the attitudes of secondary school students towards the values of basic models of experiential learning. The empirical research method was a survey (survey research procedure), and was applied to a suitable sample of 308 secondary school students from the area of Banja Luka, Prijedor and Mrkonjić Grad. A specially constructed scaler (SVMIU) with eight subscalers with a total of 40 claims on a five-point Likert-type scale was used. The results of the empirical research confirmed the basic hypothesis that secondary school students have formed attitudes toward the value of experiential learning (Mean 3.41 from a maximum of 5.00), as well as the hypothesis about the interconnectedness of their attitudes toward the values of individual models of experiential learning (significance at 0.01). The results of the research indicate the need for further studies of the connection between experiential learning and learning during instruction (formal learning) and other forms of non-formal and informal learning.
\end{abstract}

Keywords: experience, transformation of experience, experiential learning, experiential learning values, experiential learning models.

\section{Literatura}

Beard, C., Wilson, J. P. (2013). Experiential Learning, London: Kogan page.

Boud, D. (1999). Relocating reflection in the context of practice: Rehabilitation or rejection?London: University of Technology.

Branković, D., Cajvert, Lj., Puhalić D. (2019). Refleksija u superiziji - teorija i praksa, u: ur. Puhalić, D., Cajvert, L. Profesionalna supervizija, Banja Luka: Fakultet političkih nauka: 198-215. 
Branković, D., Perović, D. (2017 b). Refleksija u kvantitativnim i kvalitativnim istraživanjima, u: Banjalučki novembarski susreti, Banja Luka: Filozofski fakultet: 353-370.

Branković, D., Perović, D. (2017 a). Refleksivna teorija iskustvenog učenja, Beograd: Učenje i nastava br. 2: 209-228.

Branković, D.(2011). Teorije i modeli iskustvenog učenja, Banja Luka: Filozofski fakultet, Radovi br.14: 89-111.

Branković, D., Perović, D. (2018). Refleksija u iskustvenom učenju, obrazovanju i istraživanju, Beograd: Pedagogija br. 1: 7-30.

Cannon, H. M. \& Feinstein, A. H. (2005) Bloom beyond Bloom : Using the revised taxonomy to develop experiential learning strategies, Developments in Business Simulations and Experiential Learning, Volume 32: 176-181.

Cowan, J.\& Stroud R. (2016) Composting reflections for development, Reflective Practice, 17 (1): 27-33.

Cowan, J. (2006). On Becoming and Innovative University Teacher: Reflection in Action, Scotland: Open university Press.

Filozofijski rječnik (1965). Zagreb: Matica Hrvatska.

Gardner, H. (1993). Frames of Mind: The Theory of Multiple Intelligences. Basic Books, NY.Glimore, W.M. (2013). Improvement of STEM Education: Experiential Learning is the Key. Modern Chemistry \& Applications, Brown University Library, volumen 1:3.

Gold, S. (2001). E-larning: the next wave of experiential learning, Developments in Business Simulation and Experiential Learning, Volume 28: 57-62.

Goleman, D. (1995). Emiotional Intelligence, New York: Bantam Books.

Griffith, R. L., Steelman, L.A., Wildman, J.L., LeNoble, C.A.\& Zhou, Z.E. (2017). Guided mindfulness: A Self-regulatory approach to experiential learning of complex skills, Theoretical Issues in Ergonomics Science, 18 (2): 147-166.

Heron, J. (1999) The complete facilitator's handbook. London: Kogan Page.

HEQCO Higher Education Quality Council Of Ontario(2016). Toronto, A Practical Guide for Work-integrated Learning.

Hoover, J. Duane (2011). Complexity a voidance, narcissism and experiential learning Developments in Business Simulation and Experiential Learning, volume 38: 97-111.

Jarvis, P. (2003). Poučavanje: teorija i praksa, Zagreb: Andragoški centar.

Jordi, R. (2011). Reframing the Concept of Reflection: Consciousness, Experiential Learning, and Reflective Learning Practices Adult Education Quarterly 61(2), American Association for Adult and Continuing Education: 181-197.

Keeton, M.T., Tate, P.J. (1978). The boom in experiential learning. Leaning by experience: what, why, how.San Francuisko: New Directions for Experiential Learning, Jossey-Bass. 
Kitchenham, A. (2008). The Evolution of John Mezirow's Transformative Learning Theory. Journal of Transformative Education: Sage Journals.

Knowles, M. S. (1990). The Adult Learner: neglected species, Houston: Gulf Publishing Company.

Kohonen V., Riitaa J., Kaikkonen, P.,Lethovaara, J. (2001) Experiential learning in foreign language education. Routledge, Teylor Francis Group.

Kolb, D. A. \& Kolb, A.Y. (2015). The Kolb Learning Style Inventory 4.0: Guide to Theory, Psychometrics, Research Applications. Experience Based Learning Systems.

Kolb, D. A., (2015). Eksperientrial Learning: Experience as the Siource od Learninfg and Development Second edition. Pearson Education.

Kolb, D., A. (1984). Experiential learning, Englewood Clifs: Prentice-Hall.Malinen, A. (2000). Towards the essence of adult experiential learning, SoPhi University of Jyväskylä.

Matijević, M. (2006). Izbor medija i didaktičkih strategija u svjetlu Daleova stošca iskustva, Zbornik radova prema kvalitetnoj školi, Split: Hrvatski prosvjetnoknjiževni zbor.

Pastuović, N. (2008) Cjeloživotno učenje i promjene u školovanju; Odgojne znanosti vol.10, br.2: 253-267.

Pec, B. (1992). Psihologijski rječnik, Zagreb: Prosvjeta.

Richards, C. (2011) Global Knowledge Convergence: What, how and why the West has much to learn from Asia and elsewhere, Paper presented to ELLTA 2012 Conference, 15-17 Feb, Penang.

Richards, C. K. \& Charungkaittikul, S. (2016). The eight pillars of lifelong education: Thailand studies.

Rječnik sociologije $i$ socijalne psihologije (1977). Zagreb: Informator.

Roberts, R.W. (2012). Beyond Learning by Doing: Theoretical Currents in Experiential Education. NY: Routledge.

Ryan, M.\& Ryan, M. (2013). Theorising a model for teaching and assessing reflective learning in higher education, Higher Education Research \& Development, 32 (2): 244-257.

Uzelac, V., Vujičić, Lj. (2008). Cjeloživotno učenje za održivi razvoj, svezak 1, Rijeka: Sveučilište u Rijeci, Učiteljski fakultet u Rijeci: 287-292.

Van Manen, Max (1977). Linking Ways of Knowing with Ways of Being Practical, Curriculum Inquiry, Vol. 6, No. 3: 205-228.

Vizek-Vidović, V., Vlahović-Štetić, V. (2007). Modeli učenja odraslih i profesionalni razvoj, Zagreb: Pravni fakultet, Ljetopis socijalnog rada br. 2: 283-310.

United Nations Decade of Education for Sustainable Development - 2005-2014, (2014). Paris: UNESKO. 